\title{
The Application of Double-deck Inorganic Composite Fire Resisting Shutters in Constructional Engineering
}

\author{
Bai-Xia ZHOU* \\ Public Security Fire Forces College, Kunming 650208, China \\ 119xiaobai@163.com \\ ${ }^{*}$ Corresponding author
}

Keywords: Fire Safety, Constructional Engineering, Fire Resisting Shutters, Inorganic Composite Materials.

\begin{abstract}
In order to prevent fire from spreading in the inner space of buildings that can be divided into different fire compartments in line with specifications. A fire resisting shutter is a rolled up in the rotary axle box at ordinary times installed in the building fire protection compartments. The fire separator on the closed opening site can be operated in the fire. The double-deck inorganic composite fire resisting shutters are special fire resisting shutters that have been developed in recent years in domestic and can satisfy standard requirements, of which unexposed surface temperature rise conditions can reach $3 \mathrm{~h}$ of fire endurance. The paper analyzes double-deck inorganic composite fire resisting shutters of constructional characteristics and fire safety performance, differing from steel fire resisting shutters and proposes problems that should be noticed of applying shutters in the constructional engineering.
\end{abstract}

\section{Introduction}

Fire resisting shutters are a kind of concealed and removable fire separators that are rolled in the rotary axle box at ordinary times and operate as fire breaking out, for the sake of preventing fire from spreading in the separated opening site. Fire resisting shutters play an important role on preventing fire spread and smoke diffusion, safeguarding personnel safe evacuation, and providing convenience for rescuers to reach the fire breaking site and fight a fire rapidly and timely, so it is widely applied in the fire protection design of constructional engineering. The common setting parts of fire resisting shutters include elevator halls, surrounding, middle and floor opening sites of escalators, large area of technical holes in production departments, and difficult parts of establishing firewalls in large area buildings, etc.

\section{Classification of Fire Resisting Shutters}

The fire resisting shutters have been developed constantly, after it started to develop and utilize gradually in the 1920s. Product quality has been improved constantly, and product categories have been enriched constantly. Nowadays, it has been widely applied to modern industrial and civil buildings with various types.

\section{Different Classification in Line with Curtain Plate Texture}

Fire resisting shutters are mainly composed of curtain plate, chair plate, guide rail, support, scroll, box, snubber, rolling portal crane, door header, manual zipper, control cabinet, heat detector, and smoke detector. According to curtain plate texture of fire resisting shutters, it can be divided into steel fire resisting shutters and inorganic fire resisting shutters. Steel fire resisting shutters use steel materials to make curtain plate, guide rail, chair plate, door header, and box, etc. Moreover, it is equipped with fire resisting shutters that conform to fire-resistant completeness and composed of rolling portal crane and controller cabinet. Inorganic fire resisting shutters mean that curtain plate is adopted inorganic fireproofing fiber to do special processing. Guide rail, chair plate, splint, door header and box are made from steel materials and are equipped with light fire resisting shutters that are composed of rolling portal crane and control cabinet and conform to fire-resistant completeness, 
heat insulation property and smoke control requirements.

\section{The Classification in Accordance with Different Fire-resistant Test Methods}

According to different fire-resistant test methods, fire resisting shutters call it, which conforms to unexposed surface temperature rise judging criteria satisfy $3 \mathrm{~h}$ fire resistance, as special fire resisting shutters, while the one that excludes unexposed surface temperature rise is called as the common fire resisting shutters. The Building Design for Fire Protection stipulates that, "in the places, where are difficult to set up firewalls, it can adopt fire resisting shutters as separators of fire compartments. When it adopts fire resisting shutters that include fire endurance judging criteria of unexposed surface temperature rise, the fire endurance won't be lower than 3 hours. When it adopts fire resisting shutters that exclude fire endurance judging criteria of unexposed surface temperature rise, both sides of shutters should be equipped with independent closed automatic water sprinkler system to protect. The duration of system water spray should not be less than 3 hours. Inorganic composite fire resisting shutters are special fire resisting shutters that conform to fire endurance judging criteria of unexposed surface temperature rise.

\section{Construction Features of Double-deck Inorganic Composite Fire Resisting Shutters}

Double-deck inorganic composite fire resisting shutters that are curtain plates developed in recent years in domestic, adopting flexible texture, outer lining fireproofing decorative cloth and anti-radiation cloth, etc., inorganic composite materials to make new-type inorganic cloth fire resisting shutters. The shutters adopt the structural style of double tracks and double curtains and apply the interstice between two curtain plates to reduce heat conduction, so as to make new-type fire separation products with heat insulation effects. The fire resistance is excellent and price is relatively cheap, so it is widely applied. The main construction differs from characteristics of steel fire resisting shutters, as shown in follows:

\section{Composite Curtain Plate of Non-ignitable Inorganic Fiber Materials}

Curtain plate of double-deck shutters adopts multiple non-ignitable inorganic fiber materials. Considering the requirements of unexposed surface temperature rise, some new materials are added on the basis of the original structure of single-deck curtain plate. Moreover, the entire non-deformability of curtain plate has been improve properly, ensuring the double-layer curtain plate that has flexible texture, larger tensile strength, anti-corrosion, anti-moisture, small space usage, and light weight, etc., characteristics.

\section{Double Guide Rails of Hot Rolled Steel Plate}

The guide rail of shutters is the double guide rails. The spacing center of the guide rail is above $200 \mathrm{~mm}$. The guide rail adopts $1.5 \mathrm{~mm}$ of hot rolled steel plate and applies type-U structure, which not only ensures fire-resistant and smoke-resistant performance, but also can coordinate with curtain plate to ensure wind pressure requirements of shutters. If it is the exposed guide rail, it should spray thinly-coated steel construction fire retardant coating on the surface.

\section{Fire Resisting Shutter Actions of Fire Detector Linkage Control}

The linkage action of fire resisting shutter system, in current days, generally adopts alarming signals of smoke sensing and temperature sensing fire detectors at both sides of shutters, namely after fire resisting shutters used by replacing firewalls receive alarming signals from two independent fire detectors in fire compartments, fire resisting shutters of linkage control will be further declined. After fire resisting shutters established on the evacuation exit receive alarming signals of any smoke sensing fire detectors in the fire compartments, fire resisting shutters of linkage control is reduced to $1.8 \mathrm{~m}$ from the ground. After it receives alarming signals of any temperature sensing fire detectors specialized for fire resisting shutters of linkage control, fire resisting shutter of linkage control is reduced to the ground. 


\section{Fire Control Power Supply Ensures Reliable Power Supply by Fire Resting Shutters}

When buildings break out of fire, common power supply will black out. In order to safeguard reliable operation of fire resisting shutters, power supply of fire resisting shutters should adopt fire control power supply. For places that multiple fire resisting shutters are reduced simultaneously, it should consider power capacity of fire resisting shutters. The power supply situation of fire resisting shutters should feed back to fire control rooms and make fire watchers master it in time.

\section{Fire Safety Performance of Double-deck Inorganic Composite Fire Resisting Shutters}

As the fire resisting shutters of fire partition, it has a fundamental difference on performance requirements of general shutters. It must be equipped with good performance, including fire protection, fire resistance, thermal insulation, smoke resistance, withstand voltage, anti-fatigue, aging resistance, corrosion resistance, good strength in high temperature and heated non-deformation. According to GB7633-87 Fire Resistance Test of Doors and Shutters, double-deck composite fire resisting shutters have good fire resistance, wind load resistance performance, and heat-shielding performance.

\section{Excellent Fire Resistance}

Double-deck inorganic composite fire resisting shutters have excellent fire resistance and conduct a fire resistance test in accordance with GB7633-87 Fire Resistance Test of Doors and Shutters. When adopting unexposed surface temperature rise as the judging criteria of fire endurance, fire endurance generally is not lower than 3 hours. The performance of inorganic special fire resisting shutters can't be compared with steel fire resisting shutters. Common and compound steel fire resisting shutters and single-curtain inorganic fire resisting shutters may have above 3 hours of fire endurance for heat radiation intensity, but judging criteria of unexposed surface temperature rise generally can't reach requirements. Therefore, the fire resistance of double-deck inorganic composite fire resisting shutters is superior to fire resisting shutters of other types.

\section{Good Wind Load Resistance Performance}

The curtain plate of fire resisting shutters should have certain wind pressure resistant strength. Under the stipulated wind pressure function, the curtain plate won't be allowed to break out of the guide rail. The curtain plate of inorganic composite fire resisting shutters is an inorganic light composite material. The wind pressure resistant strength is interior to steel fire resisting shutters. In order to ensure that the curtain plate of inorganic composite fire resisting shutters has sufficient strength under the function of pressure difference, it is necessary to establish wind-resistant hook to fix shutters. When splicing the curtain plate, both sides also apply ribs of galvanized sheets to strength. In this way, this not only increases the wind pressure resistant strength to ensure that the curtain plate won't break out of the curtain plate, but also plays a role of decoration.

\section{Reduction of Decay Resistance for Curtain Texture}

The curtain plate of inorganic composite fire resisting shutters generally adopts asbeston and A-level non-inflammable building materials. The decay resistance is inferior to steel fire resisting shutters, so it is not suitable for places that may generate corrosive materials.

\section{Technical Problems of Double-deck Inorganic Composite Fire Resisting Shutters in the Engineering Application}

In recent years, with the increase of large-span door opening and ultrahigh door opening in various public buildings, users in turn need new-type shutters with light weight and large span. Thus, inorganic fire resisting shutters are new generation of fire resisting shutters, for the sake of satisfying such a demand. However, due to light weight, small scroll deflection and large span of shutters, it can provide fire separation equipment that can conform to specification requirements for fire compartments of various large-scale public buildings. The application prospect is extremely 
wide. However, inorganic composite fire resisting shutters should pay attention to the following problems in using:

\section{Main Stand-by Power Source Trouble Signal Feedback of Fire Resisting Shutter Controllers}

According to specification requirements, when main stand-by power sources of fire resisting shutter controllers break down, it should give out sound and lighting fault signals within 100s and send trouble signals to fire linkage control equipment, so as to find out faults and debug in time. However, in actual engineering, many projects don't send trouble signals of fire resisting shutter controllers to the fire linkage controllers through modules, because measurement technique of fire-fighting equipment only inspects functions and appearance of fire resisting shutters, but neglects inspection of trouble signal feedback functions. In ordinary management, power supply of fire resisting shutter controllers is turned off on purpose, and fire control rooms can't alarm in time and leave behind hidden danger.

\section{Supervision on Fire Resisting Shutter Linkage Feedback Signals}

According to specification requirements, when fire resisting shutters inspect and receive stimulated fire signals, it requires fire resisting shutters to linkage launch in line with normal procedures and should send every action signal of fire resisting shutters to fire control rooms, so that operators on duty can master action situations of fire resisting shutters in time and make a rapid response to abnormalities.

\section{Increase of Alarming Functions for Plate Resistance of Fire Resisting Shutters}

In the using process, fire resisting shutters are common to have the situation that blocked articles can't be fallen. When someone inspects management measures, there is a sign that "don't pile up articles under the shutters" on the spot. However, because stream of people and logistics are dynamics, fire resisting shutters should be blocked by articles at any time. Once it takes place fire, fire resisting shutters can't be descent effectively and can't play a role of fire separation. For such an important trouble link, it should reinforce measures, guard in advance and call the police. It suggests that it should install alarming equipment on the fire resisting shutters. As long as articles put under the fire resisting shutters exceed 20s, it will alarm. The method of blocking detection can adopt the infrared ray detection method. If the technology still can implement, it will enhance reliability of fire resisting shutters obviously.

\section{Selection of Scroll Texture}

When steel temperature rise is increased to $1000^{\circ} \mathrm{C}$, the steel heat conductivity coefficient is defined as $37.5 \mathrm{w} / \mathrm{m}^{\circ} \mathrm{C}$ approximately. According to the experiment, with the increase of temperature, modular ratio of common hot rolled steel is higher $20 \%$ than elasticity modulus of cold rolled steel. Under the heated conditions of hot rolled steel, mechanical property and non-deformation performance can be kept relatively better. Therefore, scroll of fire resisting shutters should select hot-rolled seamless steel with better mechanics deformation performance, ensuring that shutters have smaller deflection under the fire conditions, so as to satisfy operating requirements of fire high temperature.

\section{Manual Press-button Control Requirements of Both Sides at Fire Resisting Shutters}

Fire resisting shutters installed on the evacuation exit should install manual rise and fall button at both sides. The button should operate in line with instruments. Operation should be stable and have no retardation. It even can't appear uniform running speed, stacked curtain plate or even derailment phenomenon. After fire resisting shutters are keeping in the bottom of linkage state, pressing any manual button at both sides of fire resisting shutters, fire resisting shutters can go up to the limit(or delay), it will go down to bottom again. 


\section{Conclusions}

With the rapid development of economic society in China, various large-scale single buildings, such as shopping malls, supermarkets, exhibition halls, terminal buildings, stations, courtyards of public buildings, large-scale underground garages and logistic warehouses, are springing up constantly. Some buildings increasingly use fire resisting shutters to do fire compartments or separation, for the sake of pursuing for space openness, building entire effect and completeness of production lines. In recent years, manufacturers of fire resisting shutters improve productions structure and manufacturing technique positively, so as to increase adaptation of fire resisting shutters. For example, curtain and padding primary forming flow line production technology can improve quality and reduce costs. Double-deck inorganic composite fire resisting shutters can satisfy fire-resisting completeness and are special fire resisting shutters that unexposed surface temperature rise won't exceed stipulated value.

\section{References}

[1] GB 14102-2005, Fire resisting Shutter[s].

[2] GA 386-2002, The fire shutter controller[s].

[3] G. P. Zhou, H. Y. Kou, Problems of applying side roller shutter to fire compartment, Fire Science and Technology. 24 (2005) 318-319.

[4] Z. B. Wang, Engineering application, detection and maintenance of fire resistance rolling shutter system, Fire Science and Technology. 29 (2010) 834-836.

[5] X. G. YU, Discussion on the applicable design of the fire roller shutter, Fire Science and Technology. 21 (2002) 37-38.

[6] Y. R. Ni, The statuesque and the future of fire proof materials, Journal of Chinese People's Armed Police Force Academy.10 (2007) 15-18.

[7] H. P. Gao, The problems and countermeasures of building fire shutter, Low Temperature Building Technology. 7(2015)16-18.

[8] K. W, Design of large span inorganic folding lift fire shutter drive system, East China Scicence and Technology.12 (2011) 12-14.

[9] H. C. Yu, The discussion of fire shutter reliability, Fire Science and Technology.6 (2014) 701-703.

[10] W. H. Chen, The analysis of fire shutter application, Construction of Science and Technology. 6 (2009)76-77. 